\title{
Individual differences in main idea identification and text summarization in EFL reading comprehension: an exploratory study
}

\section{Gicele Vergine Vieira Prebianca}

Doutoranda no Programa de Pós-Graduação em Letras Inglês e Literatura Correspondente da Universidade Federal de Santa Catarina. Atualmente é professora da Associação Educacional do Vale do Itajai-Mirim, atuando principalmente nos seguintes temas de pesquisa: aspectos cognitivos da produção oral em lingua estrangeira (L2), estratégias de comunicaçāo, acesso lexical e memória de trabalho em L2.

Abstract: This exploratory small-scale study investigates EFL learners' ability to read in a foreign language, particularly their main idea identification and text summarization skills as products of their reading comprehension processes. Four pre-intermediate students, classified as good and poor language learners, participated in the study. Learners were asked to read a text; select its main idea(s) based on a list of options provided and then, write a summary of the main points addressed in the text. Results suggest that poor and good language learners did differ in what they consider important in a text and that level of proficiency appears to influence learners' ability to select and summarize important information.

Key-words: main idea identification; text summarization; EFL reading comprehension; reading/writing skills

Resumo: Este estudo exploratório em pequena escala investiga a habilidade dos aprendizes de ler em língua estrangeira, particularmente suas habilidades de identificar a idéia principal e resumir o texto, como oroduto do processo de compreensāo da leitura. Quatro alunos de nivel pré-intermediário, classificados como bons' e 'pobres' aprendizes de lingua estrangeira, participaram do estudo. Eles leram um texto, selecionaram sua(s) idéia(s) principal(ais) baseados em uma lista de opcóes fornecida pelo pesquisador e, em seguida, escreveram um resumo dos pontos mais importantes abordados no texto original. Os resultados sugerem que 'bons' e 'pobres' aprendizes de fato apresentam diferenças quanto ao que consideram importante em um texto, e que o nivel de proficiência dos mesmos parece influenciar suas habilidades de selecionar informaçōes importantes e resumi-las.

Palavras-chave: identificaçäo de idéia principal; resumos do texto; leitura e compreensảo em lingua estrangeira; habilidades de leitura/escrita. 



\section{Introduction}

Over the last few years, a discussion on the ability of reading and its importance to the mastering of the language as well as to the possibility of having access to the right information has been raised. According to Gagné, Yekovich and Yekovich (1993), reading plays an essential role in our society, since being functionally literate does not guarantee a social survival anymore. In other words, being able just to sign one's own name, read traffic signs or buses' labels does not make a person a skilled reader, nor gives him/her the necessary conditions to deal with reading skills needed in day-to-day life.

From a cognitive/psychological perspective, a skilled reader has been conceived as being capable of recognizing printed signs (letters or words) and creating a mental representation of these signs in his/her mind. After selecting the most appropriate mental representation to fit a certain context (i.e. lexical access and parsing), the reader still needs to be able to integrate, summarize and/ or elaborate on pieces of information in order to get a picture of what is being read. Additionally, during or after the process of reading, a skilled reader is supposed to check if comprehension really took place (comprehension monitoring) (GAGNÉ, YEKOVICH \& YEKOVICH, 1993; JUST \& CARPENTER, 1987).

Readers' main goal in undergoing all these mental processes, in fact, is to digest the written text and break the code into its central ideal. Finding out the gist in a text has been considered fundamental to comprehension and to the development of the reading ability as a whole (WILLIAMS, 1988; AFFLERBACH, 1990). Therefore, this paper builds upon research investigating the relationship between readers' capacity to identify main ideas and using them as product of reading comprehension by means of text summarization. 


\section{Review of the literature}

\subsection{Reading comprehension and main idea identification}

In order to investigate individual differences it is relevant to take into account how reading is conceptualized and what is involved in the construction of such a challenging skill. Aebersold and Field (1997), in the chapter What is Reading, describes three terms that help to constitute the act of reading: the reader, the text and the interaction between one and the other.

According to the author, the way readers face the reading process depends on several variables: (i) the way readers were introduced to reading and reading experiences they had in the past; (ii) the influence of the family in modeling readers' attitude towards reading; (iii) the influence of the educational setting, in which readers may share common or, on the contrary, be in contact with different values from different communities; (iv) differences in individual styles or characteristics and (v) the background information readers bring to a text including their values and life experiences - schema.

As important as these factors influencing readers' reading habits is the text. Aebersold and Field (1997) asserts that text type and text structure features can lead readers if not to a full comprehension, at least to a partial one. Finally, the author emphasizes the interaction between readers and texts. They conceptualizes reading as "what happens when people look at a text and assign meaning to the written symbols in that text" (p. 15). In other words, reading in itself is constituted by readers' purpose for reading and the manner or strategies they use to grasp the meaning of the text.

Taking into account the interactional perspective from which reading can be understood, it is relevant to analyze how readers are able to reach successful comprehension having to deal with so many variables. As pointed out by Daneman (1991), reading comprises a series of lower - and higher-level processes, which go 
from decoding the written code to integration of information being extracted from the passage with knowledge previously stored in readers' long-term memory. However, in order to be able to undergo these mental processes successfully aiming comprehension, readers need to have at their disposal declarative and procedural knowledge. Whereas the former refers to readers' knowledge about the code, (i.e. letters, morphemes, words, propositions, schemata), the latter consists of knowledge of reading skills necessary to reach comprehension (GAGNÉ, YEKOVICH \& YEKOVICH, 1993). According to these authors, the component reading processes fed by declarative and procedural knowledge are: (i) decoding - the ability to crack the written code and associate it with a mental representation of the word meaning in memory; (ii) literal comprehension - involves lexical access (selection of the most appropriate interpretation of the word's meaning in the reader's mental lexicon) and parsing ('construction' of syntactic and linguistic connections between words in order to form meaningful propositions); (iii) inferential comprehension - the ability to go beyond what is explicitly stated in the text by applying integration processes (connecting two or more propositions in a text), summarization (producing a macro-structure of the text in order to understand the main ideas of the passage), and elaboration ( the use of background knowledge to support a meaning representation of the text); and, finally, (iv) comprehension monitoring - involves strategies aiming at checking if comprehension is taking place, consequently reaching reader's goals. All these component-reading processes need to function properly if comprehension and main idea identification are to occur.

Individual differences in reaching successful comprehension have been accounted for the fact that many readers are not able to identify the theme or the gist of a written passage, hence, failing to recognize and structure hierarchical information (JUST \& CARPENTER, 1987, p. 
467). A study carried out by Palinscar \& Brown, 1984 (in JUST \& CARPENTER, 1987) suggests that training readers on the ability to organize information in a text is essential to improve their comprehension and develop their use of high-level comprehension processes.

As pointed out by Gagné and Yekovich \& Yekovich (1993), in order for readers to be capable of identifying main ideas in a written passage, they need to apply summarization processes. These processes rely basically on readers' declarative knowledge, since readers frequently need to make inferences in order to create a macro-structure for the text, especially when the central message is not explicitly stated. Without having this declarative knowledge readers fail to perceive the connections among propositions in a text. Nevertheless, procedural knowledge is also required to the process of summarization so that readers can know how to apply reading strategies such as selecting a topic sentence and locating text-based signals that lead to the construction of the macro-structure.

Identifying main ideas in any type of communication has been a great challenge to language users; but, on the other hand, it is also essential to successful comprehension, since it is considered the basis for perceiving relevant information and drawing appropriate inferences from a text, in order to construct its meaning. However, researchers lack consensus on a definition for main idea (WILLIAMS, 1988). According to Williams, this makes it difficult to compare results across studies as well as to establish a basis for curriculum development. The author also raises the issue that different text types can present a different approach in relation to main idea definition. Hence, the information considered relevant in a particular genre, may not be so important to another. In addition, readers may not share the writer's perspective, therefore building a different macro-structure for the text. Readers may have different purposes, expectations and prior knowledge while reading a specific passage. Williams 
(1988) also claims for the importance of text structure and linguistic signs (formal schemata as termed by Carrell, 1984a) in the recognition of important information in a text. According to her, many aspects of the text can serve as cues to the reader, so that he/she can organize the information in a hierarchical fashion.

In a study conducted by Roller (1985), readers' and writers' perception of important information in expository prose differed in relation to different tasks. One of the tasks consisted of rating important information in a paragraph, whereas the other task required a written summary of the important information students had acquired in the same paragraph. Results showed that in the importance-rating task, reader-based factor influenced readers' perception of important information. Conversely, writers' perception of important information was influenced by text-based factors.

As previously stated, background knowledge plays an important role in the identification of main ideas in a text, especially when they are implicit. Afflerbach (1990) carried out a study aiming at investigating the strategies used by anthropology and chemistry readers while constructing main ideas from familiar and unfamiliar topics. Data analysis revealed that the process of constructing main ideas was more effective when text content was familiar. Students who did not have the prior knowledge for the text made use of comprehension strategies to come up with the main ideas. Thus, Afflerbach claims that main idea construction is often a strategic behavior.

Regarding the great deal of ambiguity surrounding the term "main idea", Schellings and Van Hout-Wolters (1995) investigated 88 secondary school students and their biology teachers in order to check their correspondences in the identification of main points in an instructional text. The findings indicate that there was a large variation between what was considered the main ideas in teachers and students' opinions. According to the authors, students' 
answers that corresponded most to their teachers' answers mentioned educational reasons for that more frequently than the ones who selected different information from their teachers, hence, suggesting that main idea identification seems to depend on readers' purposes as well as on the context in which the text is being read. In fact, in previous studies, Van Hout-Wolters (1986, 1991a, as cited in SCHELLINGS \& VAN HOUT-WOLTERS, 1995) points out three approaches used to identify the main idea in a text: (i) the linguistic approach - "...the structure of the text itself determines what its main points are"; (ii) the cognitive-psychological approach - "...main points in a text depend primarily on reader variables, such as the reader's personal goals, interests, and previous knowledge"; (iii) the educational approach - "...main points in an instructional text depend on instructional variables, like instructional objectives, task demands, and test questions asked by the teacher" (p. 742).

For the sake of this study, the term "main idea" is going to be understood as readers' ability to identify important information in a text, following Van HoutWolters' $(1986,1991$ a, as cited in SCHELLINGS \& VAN HOUT-WOLTERS, 1995) linguistic approach.

\subsection{Summarizing texts}

In a cognitive dimension of the relationship reading/ writing, the abilities to compose and comprehend texts seem to share knowledge and processes in the construction of meaningful ideas (CARSON, 1993). Evidences of shared knowledge can be found in studies correlating reading/ writing performances, which show that better readers tend to produce a more mature writing, whereas better writers tend to read better and more than poorer writers (STOTSKY, 1982; BELANGER, 1987, AS CITED IN CARSON, 1993, p. 87).

As proposed by Kucer (1987, as cited in CARSON, 1993), one shared process consists of readers/ 
writers' use of cognitive mechanisms in the comprehension and production of texts. These mechanisms comprise the use and transformation of background knowledge into the text itself, use of the written code and use of common processing patterns to read and write (p. 87). Research interested in examining reading/writing cognitive processes has focused on activities such as text summarization (CARSON, 1993).

Summarizing comprises both reading and writing skills and is often named 'macrostructure abstraction' or 'main idea comprehension' (HARE, 1992). According to Schellings and Van Hout-Wolters (1995), readers' ability to find out the main points in a text is crucial for summarization, since it involves condensing the whole meaning of the text into its gist.

In order to summarize information, Kintsch and Van Dijk (1978, as cited in CARSON, 1993) proposed that readers might delete unimportant propositions; generalize irrelevant information; and/or construct inferences from a text. Based on this model of text summarization, Brown and Day (1983, as cited in WILLIAMS, 1988) investigated students from fifth grade to college level and formulated an expanded set of rules for summarizing text, which included deletion of irrelevant and/or redundant information; substitution of superordinate terms for a list of items; selection and/or invention of a topic sentence. According to the authors, the invention rule was the most complex of all; only expert writers were able to employ it in their summaries (WILLIAMS, 1988, p. 9).

Hare (1992) claims that summarizing may occur during and after comprehension. In order for a summary to be constructed during comprehension, readers need to be able to integrate and relate different propositions in a text. In this case, text summarization can be viewed as a reading activity. Yet summarizing after comprehension implies identifying the main points, deciding which ones are necessary to include in the summary and which ones can be left implicit as well as condensing the ideas in a 
coherent and cohesive fashion. Moreover, when summarizing after comprehension, readers' personal interpretations should be left apart, in order not to interfere in the meaning of the original text (HARE, 1992).

In order to be capable of writing a summary, either during or after comprehension, it seems that readers need to develop awareness of what a good summary is. Fletcher (1986, as cited in WILLIAMS, 1988) argues that even when readers have the necessary knowledge to construct a good summary, this does not guarantee a successful written performance. In a similar fashion, Johnson (1983, as cited in HARE, 1992) asserts that "comprehension does not automatically result in the ability to summarize; it only guarantees input for the summarizing processes of selection and condensation" (p.100).

In a study aiming at improving advanced reading comprehension, Bensoussan and Kreindler (1990) trained two different groups of students in the abilities to summarize text and respond to short-answer questions in order to check which group would yield more effective readers. Results showed that both groups improved consistently, therefore, making it impossible to attribute this fact either to summarization or to the answering of the questions.

Winograd (1984) reports a study carried out to analyze strategy differences between good and poor readers as they summarized texts. The findings suggested that poor and good readers differed in recognizing important information in a text as well as in what and how they included it in their summaries. Therefore, the author claims that when readers face problems in comprehension, they should be fostered to make use of reading strategies to be able to get the central message being conveyed in the text.

Summing up, it has been showed by studies in the area that text summarization needs to be understood as a product of reading comprehension, since the ability to write summaries seems to be constrained by what 
readers/writers know about the topic of the text, their sensitivity to what parts of the text are important, and their capacity to select, integrate and organize incoming information from the text in order to build a coherent mental representation of its central message. Having this in mind, the current study investigated EFL learners' ability to read in a foreign language, especially their ability to determine important information in the text and apply it to the summarization task.

\section{The study}

\subsection{Objective of the study and Research Questions}

The present study aimed at investigating EFL learners' ability of reading in a foreign language. The main objective was to analyze individual differences in terms of main idea identification and text summarization as products of reading comprehension in EFL. In order to pursue this goal, two research questions were addressed:

1. Do poor and good language learners differ in recognizing main ideas in a text and employing them in their written summaries?

2. What macro rules for summarizing texts can be found in the summaries of poor and good language learners - deletion of unimportant information, generalization or construction of inferences (KINTSCH \& VAN DIJK, 1978)?

\subsection{Participants}

Four pre-intermediate students regularly enrolled at the English Extra Curricular Course of the Federal University of Santa Catarina participated in the study. Participants ranged from 19 to 51 years old and were classified as poor and good.language learners according tc a written test developed to access their knowledge about the four initial units of their course book - New Interchange 2A. The test was part of learners' requirements 
to the course. Due to time constraints no other test aiming at checking learners' reading ability specifically was applied. The dyad composed by poor readers participants 1 and 2, scored 3,0 and 4,0 in a ten-point scale test, respectively. In the same test, participants 3 and 4 - the good-reader dyad, scored 8,8 and 8,4 , respectively.

\subsection{Method}

Participants were asked to read a four-paragraph text and select the main (s) idea (s) for it based on a list of options provided by the researcher. Learners were free to select as many main ideas as they wanted. In order to activate their schemata, a previous and informal discussion about the topic of the text was carried out before the reading task. After reading then, learners were asked to write a summary of the main points addressed in the text. During text summarization, participants did not have access to the list of ideas previously selected, in order to avoid verbatim copies. The summaries were supposed to be written in learners' L1 - Portuguese, so that the negative effects of lacking knowledge about the L2 would be minimized.

As far as the concept of main idea lacks consensus in the literature, three external proficient readers were asked to read the text and select, from the same list of options, what they believed would be considered the central message conveyed by the text. According to the external readers, four statements were classified as being the main ideas:

(i) Radioactivity is in the air, in the food we eat and in our bodies.

(ii) The Earth formed 4500 million years ago as a result of radioactivity

(iii) Trying to become stable, unstable atoms rearrange themselves producing radioactivity

(iv) Radioactivity is a natural process, but it may be dangerous if not controlled. 
The text selected for the experiment was an expository text taken from New Scientist magazine, republished in the course book Password: English 3. Due to time constraints, no analysis of the readability of the text such as lexical density was conducted. However, the text was chosen due the fact that it was published in a textbook therefore, it was expected that the text had been revised and somehow manipulated in order to foster learners' comprehension. The text as well as the list of options given to the participants for the recognition of the main ideas can be seen, respectively, in Appendices $A$ and $B$.

\subsection{Data analysis and discussion of the results}

Data was analyzed from a qualitative perspective, which aimed at showing the relationship between main idea identification and text summarization as a reflection of readers' comprehension of the text and their ability of synthesizing relevant information from it.

Regarding research questions 1 and 2 (Do poor and good language learners differ in recognizing main ideas in a text and employing them in their written summaries? What macro rules for summarizing texts can be found in the summaries of poor and good language learners - deletion of unimportant information, generalization or construction of inferences (KINTSCH \& VAN DIJK, 1978)?, the following issues emerged from the analysis of the results (see Tables 1 and 2, in Appendix C):

$$
\text { Participant 1: the learner made use of }
$$
examples and minor details in her summary, therefore, failing to apply the macro-rule of deletion of unimportant information. Although she was not able to spot all main points in the text, the statement selected by the learner as the main idea seems to have been simply translated from the topic sentence in the original written passage. Additionally, participant 2 was not able to 
employ both the rule of generalization and creation of inferences.

$>\quad$ Participant 2: the learner was able to identify two of the four main ideas provided by the external raters. Besides applying these ideas, participant 2 also inserted many details and examples in the construction of his summary. The learner failed to go beyond information explicitly stated in the text, by drawing inferences. He also seemed not to be sensitive to decide which points were important in order to be included in the summary. Moreover, no macro-rule of generalization was applied. Participant 2 tended not to synthesize information across paragraphs, by integrating ideas in order to come up with his summary. All statements present in his text were simply reductions and paraphrases from the original passage.

Participant 3: the learner could select three of the main ideas provided in the list of options and apply them in text summarization. However, in order to express these ideas in a more synthesized way, participant 3 applied the macro-rule of generalization. Therefore, changing from "Radioactivity is in the air, in the food we eat and in our bodies" to "A radioatividade sempre existiu (...) e está em toda a nossa volta" and; "Trying to become stable, unstable atoms rearrange themselves producing radioactivity" for "(...) é conseqüência da mudança de átomos instáveis". Although participant 3 did insert irrelevant information in his written summary, he attempted to make them as concise as possible. It seems that the learner was worried about providing a picture of the text so that other readers could construct a general idea 
of it, without the need to read the original passage. According to Hare (1992) readerbased summaries need to fit the audience's demands, thus, requiring to the writer a deeper processing of information to get to the gist of the text and convey it without forgetting brevity. An aspect that differentiated participant 3 from the other participants was the fact that he was able to go beyond what was clearly stated by the writer. Based on explicit information, he concluded that radioactivity is also used for warlike purposes, by applying the macro-rule of constructing inferences.

$>$ Participant 4: this participant was able to identifying three main ideas in the text and employ them in his summary. However, he could not stick to the main points by deleting unimportant information, hence mentioning secondary ideas. During text summarization, the learner appears to follow a very similar text structure to the original passage. He also attempted to include chunks of information in the same order as presented in the text, only translating them to his L1. Hare (1992) argues that readers usually prefer to copy and order ideas from the original text when summarizing due to the great risk of synthesizing information across paragraphs and sacrificing important ideas. Macro-rules of generalization and creation of inferences could not be found in his summary.

The fact that summaries tended to contain basically information translated from the original text may be accounted for two different reasons: (1) while summarizing readers could have access to the text, which might have influenced in the decision of what and how to include information in their summaries; and (2) participants might 
have experienced difficulties in paraphrasing processes, which would imply literal comprehension and consequently, literal translation.

As results show, there seems to have a contradiction between what learners considered relevant and what they included in their summaries. Data analysis showed that, although participants were able to identify some of the main ideas pre-established by the external readers and employ them in their summaries, they were not able to mention the other ones they selected believing to represent the central message of the text. An explanation for this fact may be that awareness does not necessarily implies production. In other words, learners may have the declarative knowledge to distinguish good from bad summaries, however, they lack procedural knowledge to put this into practice (HARE, 1992). Failing to have enough procedural knowledge in order to write summaries is a factor closely related to L2 language skills, since reading and writing abilities demand a great cognitive effort and are likely to burden L2 language users (KIRKLAND \& SAUNDERS, 1991). Even though participants were writing in their L1, L2 proficiency might have been a strong factor influencing learners' ability of identifying and synthesizing important information.

Lack of L2 proficiency may also have accounted for learners' difficulties in recognizing the relation among subordinate and superordinate ideas in a text. More proficient readers are able to construct a coherent macro representation of the text, thus, relying on top-down processes, whereas less proficient readers tend to read and comprehend in a more bottom-up fashion, preventing them from perceiving superordinate information, hence frequently resulting in mere paraphrasing of ideas, instead of integration (KIRKLAND \& SAUNDERS, 1991).

In the present study, both poor and good language learners appeared to activate relevant schemata in order to summarize the text. To some extent, both were able to spot main points in the text and mention them in their final 
product. The level of prior knowledge learners have on text content domain also appears to bias reading/writing activities. According to Afflerbach (1990), several reading process components are facilitated by the activation of background knowledge, among which the ones responsible for assigning importance to text, necessary for main idea construction. Text summarization is also influenced by the use of prior knowledge, since the recognition of certain patterns of text types and structures may aid in the perception and manipulation of hierarchical elements in a text. As stated by Hare (1992),

...summarizing activities presume some prior knowledge of the content of the text to be summarized. It is difficult - if not impossible - to summarize text content that is completely novel because all ideas may seem equally important or unimportant. The summarizer cannot tell which information to include and which to delete, except by conscientious attention to lexical signals and to text structure patterns (p. 114).

Summing up, despite the fact that participants did not show great significant differences in identifying and employing main ideas in text summarization, it became clear that reading/writing relationship presents complex processes, which many times may cause learners' cognitive overload, thus preventing them from reaching successful comprehension, since in order for learners to be able to comprehend a text written in L2 and summarize it in their L1, they need to process textual information and store it for a short period of time so that they can condense and integrate ideas across paragraphs as well as report them in their native language. All these processes depend on learners' cognitive processes of processing and storage, which occur within the limitations of readers' working memory system. As pointed out by Afflerbach (1990), when reading processes are not automatized (as in less proficient readers, for example), readers may encounter 
difficulties to reach comprehension, therefore; resources from working memory are reallocated in order to solve the problem, thus leaving less resources available for the other processes such as condensing information, in this case. Hence, it seems plausible to conclude that limited working memory resources may affect the overall quality of main idea identification, text summarization and comprehension in L2 and in L1.

\section{Final Remarks}

Results from the present study suggest that poor and good language learners did differ in what they consider important in a text. Sensitivity to importance and efficient use of the macro-rules in order to transform the text into its gist have proved to have a connection. In addition, participants' proficiency level also appeared to have a strong influence in the development of their abilities of selecting and condensing relevant ideas, despite the fact they were writing in L1.

Considering the selection of main points, results indicate that learners tended to rely on the cognitivepsychological approach rather than on the linguistic approach. They seemed to determine what was relevant according to their personal purposes and expectations while reading the text. In this case, the macro-rules for summarization apparently follow the same fashion. Drawing inferences from text in order to construct or identify main ideas showed to be the most difficult macrorule to be applied. This fact may be due to learners' level of proficiency in L2, since only the good language learner (the oldest as well) was able to employ this specific rule, thus, suggesting that the use of macro-rules and summarizing skills might be improved as readers gain language experience.

One limitation of the study, which might have biased the use of macro-rules for summarization, was allowing readers to have access to text while summarizing. 
This may have influenced learners to follow the same text structure used by the writer in the original passage as well as to select what information should be included in the summaries. A possible way to have a more consistent pool of data should be to investigate a larger number of participants and prevent them from having access to the text while synthesizing information. Another relevant shortcoming to be mentioned is the fact that the text did not contain a title, which could have facilitated learners' prior knowledge activation and consequently, main idea identification.

Suggestions for further research would be analyzing main idea identification and text summarization across levels of proficiency with a larger number of participants. Providing text with familiar and unfamiliar topics as well as applying questionnaires to investigate readers' difficulties in selecting and condensing information would also help researchers to have a clearer picture of the cognitive processes involved in reading/writing activities. Another interesting suggestion would be training a group of learners in main idea identification and another one in techniques for text summarization in order to analyze which instructional approach would be able to develop more efficient readers. 


\section{References}

AEBERSOLD, J. A.; FIELD, M. L. What is reading? In: From reader to reading teacher. New York: Cambridge University Press, 1997.

AFFLERBACH, P. P. The influence of prior knowledge on expert readers' main idea construction strategies. Reading Research Quarterly, 1, 41-46, 1990.

ANDERSON, R. C.; PEARSON, P. D. A schema-theoretic view of basic processes in reading comprehension. In: P. L. Carrel, J. Devine, \& D. E. Eskey (Eds). Interactive approaches to second language reading. New York: Cambridge University Press, 1998.

BENSOUSSAN, M.; KREINDLER, I. Improving advanced reading comprehension in a foreign language: summaries vs. short-answer questions. Journal of Research in Reading, 13(1), 55-68, 1990.

CARSON, J. G. Reading for Writing: cognitive perspectives. In: CARSON, J.; LEKI, I. (Eds) Reading in the composition classroom: second language perspectives. Heinle \& Heinle, 1993.

DANEMAN, M. Individual differences in reading skill. In: BARR, Rebecca; KAMIL, Michael L.; MOSENTHAL, Peter; PEARSON, P. David (Eds.). Handbook of reading research. Vol. II. New York: Longman, 1991.

DONIN, J.; SILVA, M. The relationship between first- and second-language reading comprehension of occupation-specific texts. In: CUMMING, A. H (Ed.) Bilingual performance in reading and writing. Ann Arbor: James Benjamins, 1994.

GAGNÉ, E. D., YEKOVICH, C. W.; YEKOVICH, F. R. The cognitive psychology of school learning. New York: Harper Collins College Publishers, 1993.

HARE, V. C. Summarizing text. In: IRWIN, J.; DOYLE, M. A. (Eds.). Reading/Writing connections: learning from research. Newark, DE: International Reading Association, 1992.

JUST, M.; CARPENTER, P. A. The psychology of reading and language comprehension. Massachusetts: Allyn and Bacon, 1987. 
KIRKLAND, M. R.; SAUNDERS, M. A. P. Maximizing student performance in summary writing:managing cognitive load. Tesol Quarterly, 25, 1, 105-121, 1991.

MARQUES, A. Password: English \# 3. São Paulo: Ática, 1995.

ROLLER, C. M. The effects of reader- and text-based factors on writers' and readers' perceptions of the importance of information in expository prose. Reading Research Quarterly, 20 (4), 437-457, 1985.

SCHELLINGS, G.L.M.; VAN HOUT-WOLTERS, B.H.A.M. Main points in an instructional text, as identified by students and by their teachers. Reading Research Quarterly, 30 (4), 742-756, 1995.

TOMITCH, L. M. B. Schema activation and text comprehension. Fragmentos, 3, 2, 29-43.

TOMITCH, L.M.B. (1996). Individual differences in text organization perception and working memory capacity. Revista da ANPOLL, 2, 71 93, 1991.

TOMITCH, L.M.B. Individual differences in working memory capacity and the recall of predicted elements in the text. Lenguas Modernas, 26-27, 31-51, 1999-2000.

WILLIAMS, J. P. Identifying main ideas: a basic aspect of reading comprehension. Topics in language disorders, 8(3), 113, 1988.

WINOGRAD, P. N. Strategic difficulties in summarizing texts.

Reading Research Quarterly, 19, 404-425, 1984. 


\section{APPENDIX A}

Radiation has become a monster of the 20th century - because it can kill. Yet radioactivity is a natural process that has occurred since the first elements began to form at the beginning of the Universe.

Many people fear radioactivity: they associate it with the fallout of atomic bombs or disasters such as the explosion at the Chernobyl nuclear power station. It is, however, a natural process, happening constantly all around us. It occurs within our homes, in the food we eat; even our bodies are radioactive.

Much of this radioactivity is a natural consequence of the composition of the rocks and soil at the surface of the Earth formed 4500 million years ago. Indeed without radioactivity, stars would not shine and the ingredients from which we and our planet are built would never have been formed.

Today, we know that this radioactivity is the result of naturally unstable atoms changing from one variety into another. The inner parts of the atom rearrange themselves in an attempt to become stable.

We also, however, deliberately create radioactive substances for purposes ranging from medical diagnosis to analyzing the structure of materials. And we create radioactive by-products, particularly in nuclear reactors. We need to treat these artificial sources with care; radioactivity may be a natural process, but it can be dangerous, particularly when it is not properly controlled.

(Source: New Scientist, February/1988, in Marques, 1995) 


\section{APPENDIX B}

List of options given to the participants:

( ) Radioactivity frightens people

( ) Radioactivity is in the air, in the food we eat and in our bodies.

( ) Rocks and soil are composed by radioactivity

( ) The Earth formed 4500 million years ago as a result of radioactivity

( ) Trying to become stable, unstable atoms rearrange themselves producing radioactivity

( ) Many people associate radioactivity with atomic bombs

( ) Radioactivity is used in the medicine for medical diagnosis and material analysis

( ) Stars shine because of the radioactivity from the Universe

( ) It is possible to create radioactive products in nuclear reactors

( ) Radioactivity is a natural process, but it may be dangerous if not controlled. 


\section{APPENDIX C}

\section{Table 1. Main ideas identified by each participant}

\section{Poor language learners}

\begin{tabular}{|l|l|}
\hline Participant 1 & $\begin{array}{l}\checkmark \text { Radioactivity is a natural process, but it may be dangerous if not } \\
\text { controlled. }\end{array}$ \\
\hline Participant 2 & $\checkmark$ Radioactivity is a natural process, but it may be dangerous if not \\
& $\begin{array}{l}\text { controlled. } \\
\checkmark \text { Radioactivity is in the air, in the food we eat and in our bodies. }\end{array}$ \\
\hline
\end{tabular}

\section{Good language learners}

\begin{tabular}{|l|l|}
\hline Participant 3 & $\checkmark$ Radionctivity is in the air, in the food we eat and in our bodies. \\
& $\checkmark$ Trying to become stable. unstable atoms rearrange themselves producing \\
& radioactivity \\
& $\checkmark$ Radioactivity is a natural process, but it may be dangerous if not \\
& controlled.
\end{tabular}

Table 2. Macro-rules for summarization used by each participant

\section{Poor language learners}

\begin{tabular}{|l|l|}
\hline Participant 1 & $\begin{array}{l}\checkmark \text { (ieneralization: "O texto fala sobre radioativade com exemplos de } \\
\text { utilização benéfica" }\end{array}$ \\
\hline Participant 2 & $\checkmark$ No use of generalization, deletion or creation of inferences \\
\hline
\end{tabular}

\section{Good language learners}

\begin{tabular}{|l|l|}
\hline Participant 3 & $\checkmark \begin{array}{l}\text { Generalization: "A radioatividade sempre existiu (...) e está em toda a } \\
\text { nossa volta": "(...) é conseqüència da mudança de átomos instáveis". }\end{array}$ \\
& $\begin{array}{l}\checkmark \text { Construction of inferences: "Seu uso varia desde fins bélicos até } \\
\text { objetivos nobres como diagnósticos médicos" }\end{array}$ \\
\hline Participant 4 & $\checkmark$ No use of generalization, deletion or creation of inferences \\
\hline
\end{tabular}

